\title{
The ecological adaptability of Phragmites australis to interactive effects of water level and salt stress in the Yellow River Delta
}

Article in Aquatic Ecology · September 2016

DOI: $10.1007 /$ s10452-016-9602-3

\section{CITATIONS}

0

8 authors, including:

\section{Bo Guan}

Chinese Academy of Sciences

26 PUBLICATIONS 216 CITATIONS

SEE PROFILE

\section{Guangxuan Han}

Chinese Academy of Sciences

42 PUBLICATIONS 418 CITATIONS

SEE PROFILE
READS

55

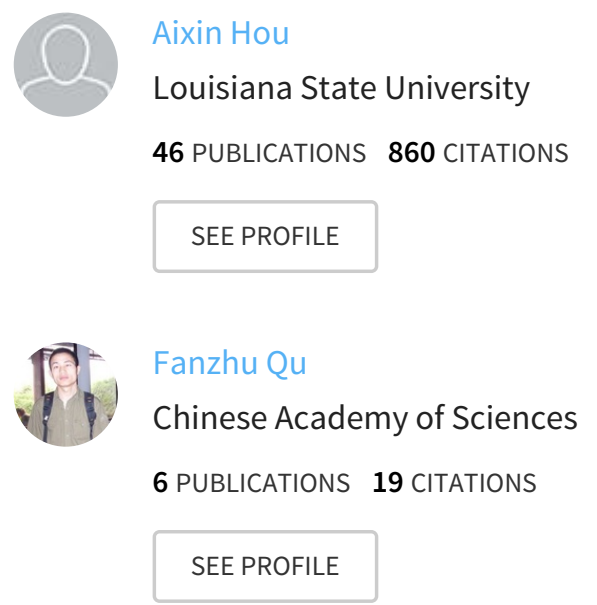

Some of the authors of this publication are also working on these related projects: 


\title{
The ecological adaptability of Phragmites australis to interactive effects of water level and salt stress in the Yellow River Delta
}

\author{
Bo Guan (D) Junbao Yu - Aixin Hou - Guangxuan Han • \\ Guangmei Wang $\cdot$ Fanzhu Qu $\cdot$ Jiangbao Xia $\cdot$ Xuehong Wang
}

Received: 2 August 2016/ Accepted: 20 September 2016

(C) Springer Science+Business Media Dordrecht 2016

\begin{abstract}
Soil salinity and waterlogging are two major environmental problems in estuarine wetlands. To prevent the typical wetland plants from degradation by soil salinization and salt waterlogging and more effectively use the plants to provide wetland ecosystem services, we examined the ecological adaptability of Phragmites australis, a characteristic plant species in the Yellow River Delta, to the interactive effects of water level and salt stress. The results showed that $P$. australis adapts to salt and water table stressed environments through slowing down the growth rate, maintaining the tiller number, and adjusting the biomass allocation of different organs. The highest plant height and the largest leaf area were
\end{abstract}

Handling Editor: Kevin Murphy.

B. Guan · G. Han · G. Wang

Key Laboratory of Coastal Environmental Processes and Ecological Remediation, Yantai Institute of Coastal Zone Research (YIC), Chinese Academy of Sciences (CAS), Yantai 264003, Shandong, People's Republic of China

B. Guan · G. Han · G. Wang

Shandong Provincial Key Laboratory of Coastal

Environmental Processes, YICCAS,

Yantai 264003, Shandong, People's Republic of China

J. Yu (ه)

Resource and Environmental Engineering Ecology, Ludong University, Yantai 264025, People's Republic of China

e-mail: junbao.yu@gmail.com at $0 \mathrm{~cm}$ water table treatment; the $0.5 \% \mathrm{NaCl}$ treatment increased the aboveground biomass; higher water table increased the fibrous root biomass allocation, but largely decreased the leaf biomass. The exclusion of toxic inorganic ions such as $\mathrm{Na}^{+}$and $\mathrm{Cl}^{-}$ and the accumulation of organic solutes are also important mechanisms to aid survival in saline wetlands. On average $35.1 \%$ of $\mathrm{Cl}^{-}$and $53.9 \%$ of $\mathrm{Na}^{+}$ accumulated in belowground organs. The study could provide fundamental guidance for wetland restoration projects and wetland sustainable use in coastal zones such as the Yellow River Delta.

Keywords Phragmites australis - Ion content . Biomass $\cdot$ Salt stress $\cdot$ Water table

B. Guan · A. Hou

Department of Environmental Sciences, College of the

Coast and Environment, Louisiana State University,

Baton Rouge, LA 70803, USA

e-mail: ahou@1su.edu

B. Guan · F. Qu · J. Xia

Research Center for Eco-Environmental Sciences Yellow

River Delta, Binzhou University, Binzhou 256603,

People's Republic of China

X. Wang

Key Laboratory of Wetland Ecology and Environment,

Northeast Institute of Geography and Agricultural

Ecology, Chinese Academy of Sciences,

Changchun 130102, People's Republic of China 


\section{Introduction}

Coastal wetlands, which are normally affected by both fresh and salt water, are important natural ecosystems that provide ecosystem services (Barbier et al. 2011). Plants in coastal wetlands, which play an important role in ecosystem services, tend to suffer a number of environmental stresses, including dramatic temperature fluctuation, strong winds, flooding, high salinity, and seawater inundation (Guan et al. 2011; Wang et al. 2012; Lucas and Carter 2013). Among those, soil salinity and flooding are often regarded as the most restrictive environmental factors affecting plant growth and distribution, and even the whole coastal wetland environment (Cui et al. 2008; Di Bella et al. 2014).

The Yellow River Delta (YRD) is one of the most active land-ocean interactive regions among the large river deltas in the world. The YRD is often called the "Golden Triangle" because massive sediment transport brings fertile soil from the Loess Plateau of central China to the river mouth, leading to the expansion of YRD by $20-25 \mathrm{~km}^{2}$ per year (Ren and Walker 1998; Wang and Liang 2000). However, the annual discharge of the Yellow River has gradually decreased in the past decades due to climate change and anthropogenic influence (Wang et al. 2006). Consequently, the freshwater wetland of the YRD has degraded, and both biodiversity and soil quality have been threatened by water deficiency and increasing salt stress (Shan 2007; Yu et al. 2013). A number of studies have determined the influence of salt and water table on typical plants in the YRD. For instance, Suaeda salsa L. Pall (=Suaeda maritima subsp. salsa (L.) Soó.), a euhalophytic herb, can grow in high salt stress environments, but cannot withstand high water table levels (Cui et al. 2008; Guan et al. 2011); while Tamarix chinensis Lour, a natural secondary forest shrub species, shows strong physiological drought tolerance (Xia et al. 2015).

Phragmites australis (Cav.) Trin. ex Steud. (often known as common reed) is one of the most widespread perennial grasses in the temperate region of the world (Brix 1999). It can be found in both shallow freshwater swamps and coastal salt marshes across North America, Europe, Australia, and Asia (Burdick et al. 2001; Mauchamp and Mésleard 2001; Wang et al. 2012; Achenbach et al. 2013; Guo et al. 2013). In the YRD, there are about 2600 ha of $P$. australis wetland, which provide staging, wintering and breeding sites for birds and may directly benefit ecological restoration of wetlands (Wu et al. 2009; Wang et al. 2012).

To prevent the $P$. australis wetlands from degradation by soil salinization and salt water flooding, and more effectively use the $P$. australis wetland ecosystem services in the YRD, it is necessary to understand the mechanism of ecological adaptability of $P$. australis to the interactive effects of water level and salt stress. Most of the previous studies of the subject were focused on the niches of $P$. australis under gradients of water depth (He et al. 2008), the biodiversity of restored $P$. australis wetlands (Wang et al. 2012), and the vegetation distribution patterns corresponding to different water depths and soil salinities in the YRD (He et al. 2007). It is difficult to explain in depth the relationship between plant growth and certain factors such as salt stress and water table levels based on field investigation of the complicated environmental elements. In this study, the interactive impacts of water table levels and salt stress on the growth of $P$. australis seedlings and their physiological responses were studied in experimental greenhouse conditions. It was hypothesized that (1) a high water table treatment could reduce the growth of $P$. australis; (2) an appropriate water level has compensatory effects on the loss of growth induced by high salt stress; and (3) the adaptive mechanism involves morphological responses, such as biomass allocation, and physiological responses.

\section{Materials and methods}

Experimental design

Clones of Phragmites australis were collected from a brackish wetland of the Yellow River Delta. All the clones were collected from a reed community, which grew in uniformity and was within a small area of $9 \mathrm{~m}^{2}$ and $10-30 \mathrm{~cm}$ vertical direction to maximize the probability of obtaining rhizomes originating from the clonal extension of a single genet (Deng et al. 2008). In order to produce similar-sized plants for the experiment, the clones were propagated by the layering of shoots in a pot filled with water in the greenhouse for 20 days, to initiate adventitious shoot growth at the stem nodes. Then, 5 similar-sized seedlings were planted in $15.7 \mathrm{~L}$ PVC pots (diameter $20 \mathrm{~cm}$, height 
$50 \mathrm{~cm}$ ) containing native sandy clay loam soils (48 $\mathrm{cm}$ from surface soil to the bottom), which was collected from the same reed community at the same time as the plant material. A permeable cloth was placed at the bottom of the PVC pots, to prevent soil leakage from the bottom. The concentrations of total nitrogen, available phosphorus, and potassium in the experimental soils were $1.40 \pm 0.21 \mathrm{~g} \mathrm{~kg}^{-1}$, $13.4 \pm 2.5 \mathrm{mg} \mathrm{kg}^{-1}$, and $222.1 \pm 13.8 \mathrm{mg} \mathrm{kg}^{-1}$, respectively, and the total salt content was $2.22 \pm 0.52 \mathrm{~g} \mathrm{~kg}^{-1}$. The day and night temperatures in the greenhouse were controlled at $30 \pm 3$ and $24 \pm 3{ }^{\circ} \mathrm{C}$, respectively. The plants were sufficiently watered every 4 days for seedling cultivation.

In total, 240 plants were used for the experiment. The treatments combined four levels of water table with three salt levels in an orthogonal design (water table $\times$ salt). The pots were placed in sinks with a depth of $80 \mathrm{~cm}$ to control a water table of -30 , 0 , and $30 \mathrm{~cm}$, respectively, and with a soil water content of 60-80 \% as a control. Forty-eight pots were divided into 12 sets according to different water table and salt gradient treatments, and each set contained 4 replicates. Three salt levels, i.e., 0, 0.5, and $1 \% \mathrm{NaCl}$, were designed in different sets of sinks.

The plants started to be watered with different levels of $\mathrm{NaCl}$ solutions after three weeks of recovery while the average plant height achieved $18.98 \pm 2.27 \mathrm{~cm}$. About a week later, the soil salt concentrations reached the desired treatment levels. Then the plots were placed into sinks which were filled with different salt solutions. Thereafter, the salt solutions in sinks were replaced every 2 weeks to avoid significant changes of salt concentrations. The pots had drainage holes in the side. These holes and the bottom of each pot were covered with permeable cloth to prevent soil seepage and allow water to enter into the pot easily.

\section{Morphological indices measurements}

The experiment lasted for 6 months. Plant height, stem diameter, tiller number (per plant), and leaf area (the second fully unfolded leaf from the top of the plant) were measured before harvest. At the end of the experiment, the harvested plants were washed with distilled water. Taproots, fibrous roots, shoots, and leaves were separated for each plant. The plant samples were oven-dried at $105^{\circ} \mathrm{C}$ for $15 \mathrm{~min}$, and then dried at $60{ }^{\circ} \mathrm{C}$ to constant weight; the dry weight was recorded.

\section{Determination of ion contents}

Dry samples of plant leaves $(100 \mathrm{mg}$ ) were treated with $20 \mathrm{ml}$ of deionized water at $100{ }^{\circ} \mathrm{C}$ for one hour, and the extract was taken for determination of free ion contents. An atomic emission spectrometer (AA-6800, Shimadzu, Japan) was used to measure sodium ( $\mathrm{Na})$ concentrations, and ion chromatography (ICS-2000, Dionex, USA) was used for chloride $(\mathrm{Cl})$ concentrations.

Determination of proline, soluble sugar and protein content

The concentration of proline and soluble sugar in the dry plant samples was measured, respectively, using ninhydrin and anthrone (Zhu et al. 1983).

For protein measurement, $0.1 \mathrm{~g}$ of fresh leaves was homogenized with $0.9 \mathrm{ml}$ of ice-cold normal saline. Homogenates were then centrifuged at $2500 \mathrm{rpm}$ at $4{ }^{\circ} \mathrm{C}$ for $10 \mathrm{~min}$. The supernatants were used for the determination of the soluble protein contents (Bradford 1976).

Data analysis

Statistical analysis was performed using IBM SPSS 20.0. Experimental data were subjected to two-way analysis of variance (salt stress and water table level as main factors), and the means were separated by the least significant difference (LSD). All acquired data were represented by the average of four replicate measurements and standard deviation (SD). Significance was tested at the $5 \%$ level.

\section{Results}

Effect of salt and water table on plant morphology

Plant heights were affected significantly by both salt $(p<0.01)$ and water table $(p<0.001)$ (Fig. 1; Table 1). As the salt stress increased, the plant height decreased significantly. Plants in the three water table treatments $(-30,0$, and 30) were taller than the control. The tallest plant was at $0 \% \mathrm{NaCl}$ treatment 

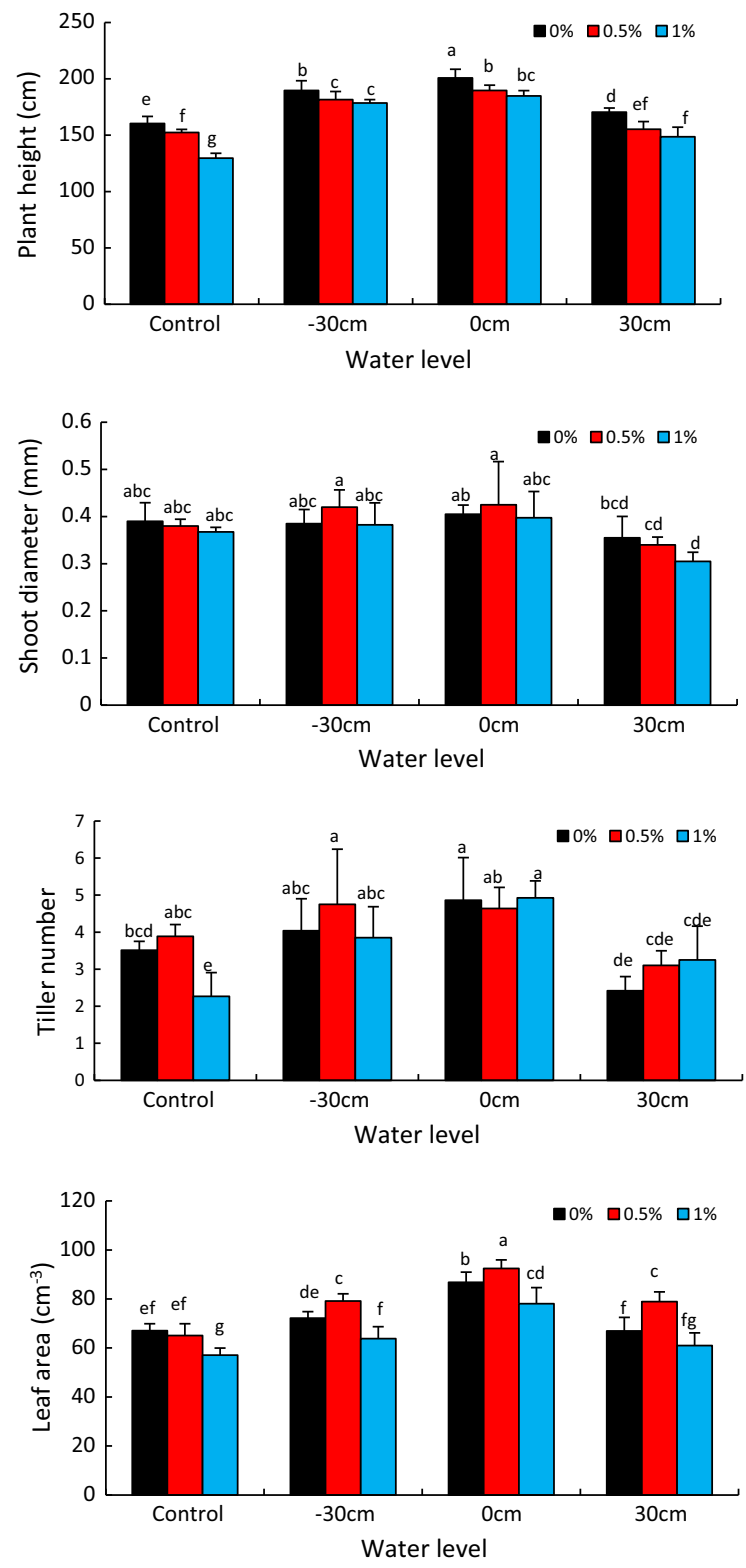

Fig. 1 Plant height, shoot diameter, tiller number, and leaf area of $P$. australis in different water table level and salt treatments. In each column, the data markers identified with the same letters are not significantly different $(p<0.05)$ according to a least significant difference test

under $0 \mathrm{~cm}$ water table depth. Among different water table treatments, the plant height decreased significantly with increasing or decreasing water table depth from $0 \mathrm{~cm}$ water table.

Shoot diameters and tiller numbers were significantly affected by water table (Fig. 1; Table 1), but no significant differences were observed between different salt stresses. The lowest shoot diameter appeared in the combination of $1 \% \mathrm{NaCl}$ and $30 \mathrm{~cm}$ water table, and the lowest tiller number in the combination of $1 \% \mathrm{NaCl}$ and control water table treatment.

Leaf area, which was stimulated by $0.5 \% \mathrm{NaCl}$ in all three water table treatments, $(-30,0$, and 30$)$, was higher than in 0 and $1 \% \mathrm{NaCl}$ treatments. Water table levels also significantly affected plant leaf area (Table 1). The highest leaf area appeared in the combination of $0.5 \% \mathrm{NaCl}$ and $0 \mathrm{~cm}$ water table treatment.

\section{Effect of salt and water table on plant biomass}

Salt stress $(p<0.05, \quad$ Table 1$)$ and water table $(p<0.01$, Table 1$)$ had significant effects on plant leaf biomass, which was highest (4.49 g/plant) in the $-30 \mathrm{~cm}$ water table level and $0.5 \% \mathrm{NaCl}$ treatment and lowest $(1.13 \mathrm{~g} / \mathrm{plant})$ in the $30 \mathrm{~cm}$ water table level and $0 \% \mathrm{NaCl}$ treatment. Shoot biomass, taproot biomass, fibrous root biomass, and total plant biomass were significantly affected by water table and the combination of water table and salt stress, but no significant differences were observed between different salt stresses (Table 1). Similar to leaf biomass, the biomass of shoot $(8.50 \mathrm{~g} / \mathrm{plant})$, taproot (13.09 g/plant), and total plant (30.16 g/plant) were highest in the combination of $-30 \mathrm{~cm}$ water table level and $0.5 \% \mathrm{NaCl}$ treatment. The fibrous root biomass showed a difference, the highest of which was $6.51 \mathrm{~g} / \mathrm{plant}$ under the combination of $0 \mathrm{~cm}$ water table level and $0.5 \% \mathrm{NaCl}$. More biomass accumulated in aboveground organs with the increasing of salt stress. The highest ratio of leaf, shoot, taproot, and fibrous root to total biomass occurred in the combination of control and $1 \% \mathrm{NaCl}$ stress, $30 \mathrm{~cm}$ water level and $0.5 \% \mathrm{NaCl}$ stress, $-30 \mathrm{~cm}$ water table level and $1 \% \mathrm{NaCl}$ stress, and $0 \mathrm{~cm}$ water level and $0 \%$ $\mathrm{NaCl}$ stress, respectively (Fig. 2).

\section{Effect of salt and water table on $\mathrm{Na}^{+}, \mathrm{Cl}^{-}$contents}

$\mathrm{Na}^{+}$content significantly increased with increasing salt stress $(p<0.05)$ and also was affected dramatically by the combination of salt stress and water table level $(p<0.05)$ (Fig. 3; Table 1). No significant differences of $\mathrm{Na}^{+}$content were observed between different water table levels. When belowground and 
Table 1 Relationships between growth parameters of $P$. australis plants and treatments of salt and water level

\begin{tabular}{|c|c|c|c|}
\hline & Salt & Water level & Salt $\times$ water level \\
\hline Plant height $(\mathrm{cm})$ & $14.479 * *$ & $47.252 * * *$ & $3.797 * *$ \\
\hline Shoot diameter $(\mathrm{mm})$ & 4.390 & $16.996 * *$ & 0.447 \\
\hline Tiller number & 1.110 & $8.469^{*}$ & 1.654 \\
\hline Leaf area $\left(\mathrm{cm}^{2}\right)$ & $27.483 * *$ & $42.203 * * *$ & 1.247 \\
\hline \multicolumn{4}{|l|}{ Biomass (g) } \\
\hline Leaf & $9.219^{*}$ & $16.19 * *$ & 1.303 \\
\hline Shoot & 2.819 & $5.83 *$ & $2.444 *$ \\
\hline Taproot & 1.378 & $9.949 * *$ & $3.672 * *$ \\
\hline Fibrous root & 0.725 & $9.751 *$ & $3.984 * *$ \\
\hline Total plant & 2.160 & $9.992 * *$ & $3.745 * *$ \\
\hline \multicolumn{4}{|l|}{$\mathrm{Na}^{+}$content $(\mathrm{mg} / \mathrm{g})$} \\
\hline Leaf & $7.843^{*}$ & 2.507 & $11.006 * * *$ \\
\hline Shoot & $9.698^{*}$ & 1.366 & $8.869 * * *$ \\
\hline Taproot & $12.766^{* *}$ & 0.669 & $2.947 *$ \\
\hline Fibrous root & $16.345^{* *}$ & 0.276 & $4.692 * *$ \\
\hline \multicolumn{4}{|l|}{$\mathrm{Cl}^{-}$content $(\mathrm{mg} / \mathrm{g})$} \\
\hline Leaf & $11.989 * *$ & $3.736 *$ & 1.975 \\
\hline Shoot & $7.428^{*}$ & 0.327 & $13.986 * * *$ \\
\hline Taproot & $17.976 * *$ & 0.041 & $2.873 *$ \\
\hline Fibrous root & $11.462 * *$ & 1.141 & $4.141 * *$ \\
\hline Proline content (mg/g) & $8.335^{*}$ & 2.500 & $10.046 * * *$ \\
\hline Soluble sugar content (mg/g) & $18.554 * *$ & 3.852 & 1.152 \\
\hline Protein content $(\mathrm{mg} / \mathrm{g})$ & 1.279 & 2.656 & $5.331 * *$ \\
\hline
\end{tabular}

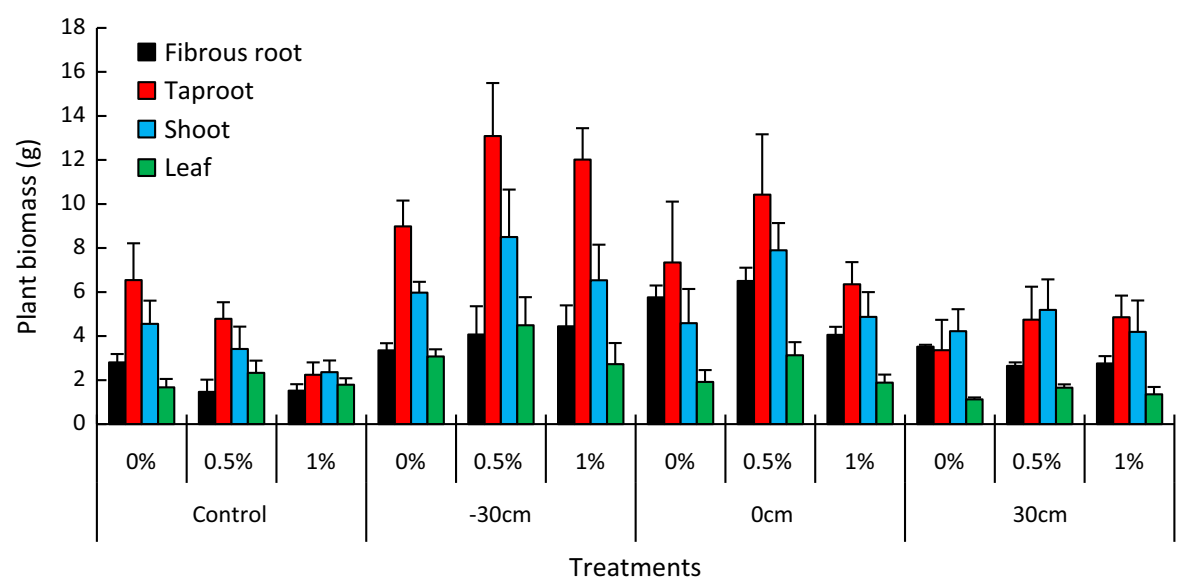

Fig. 2 Leaf, shoot, taproot and fibrous root biomass of $P$. australis in different salt and water table level treatments

aboveground plant portions ware compared, an average $53.9 \%$ of $\mathrm{Na}^{+}$accumulated in the belowground portion. The percentage of $\mathrm{Na}^{+}$in roots (taproot and fibrous root) slightly increased with increasing soil salt when the water level was below ground (control and $-30 \mathrm{~cm}$ water table), but as the plant was inundated with water $(0 \mathrm{~cm}$ and $30 \mathrm{~cm}$ water table $)$, the aboveground plant (leaf and shoot) accumulated more $\mathrm{Na}^{+}$ with the increasing salt stress (Fig. 3).

A similar trend was observed in $\mathrm{Cl}^{-}$content, which was also increased significantly by salt stress $(p<0.001$, Fig. 3 ; Table 1$)$. No remarkable 
Fig. $3 \mathrm{Na}^{+}$and $\mathrm{Cl}^{-}$content in leaf, shoot, taproot and fibrous root of $P$. australis in different salt and water table level treatments
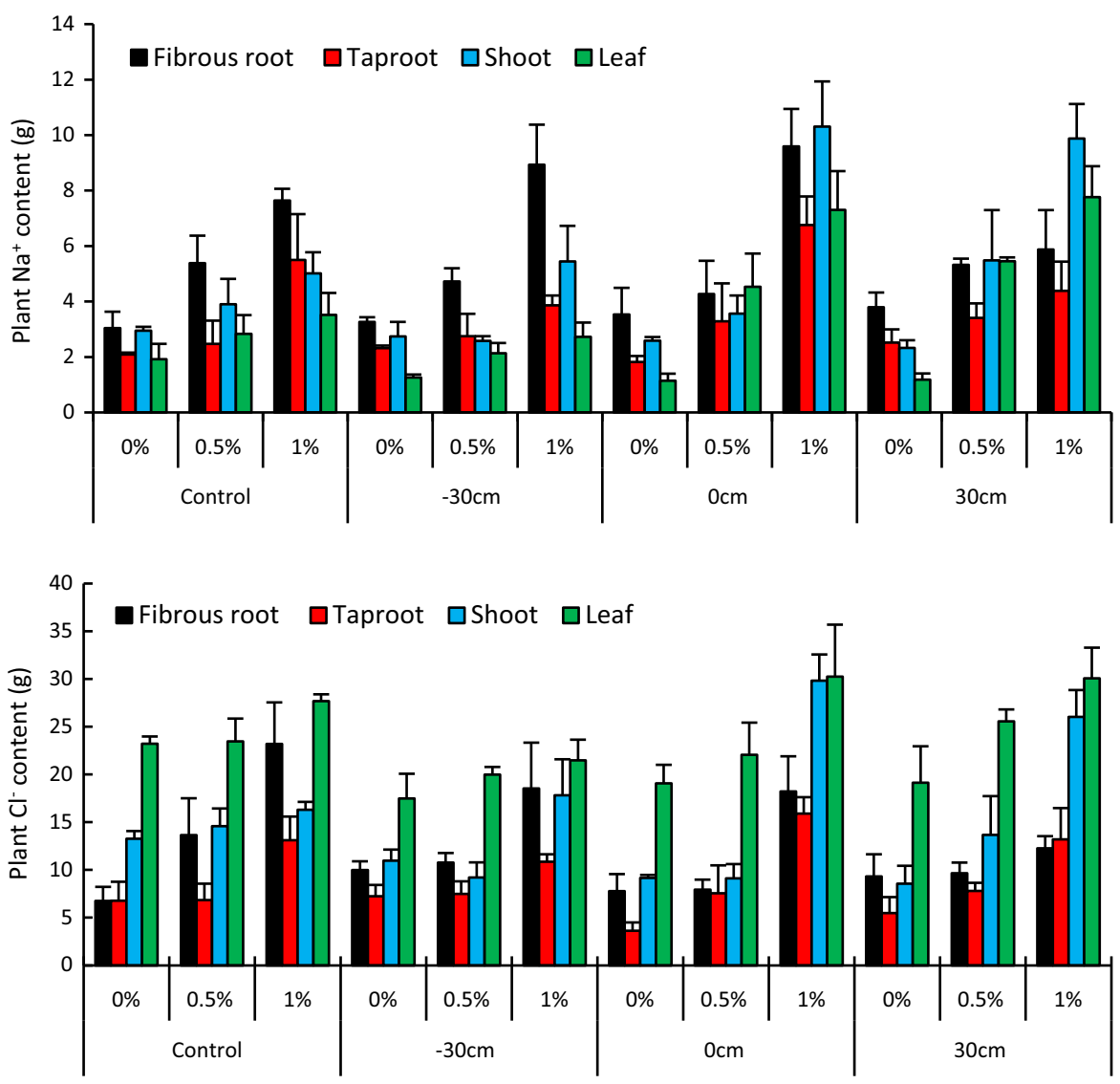

differences in the $\mathrm{Cl}^{-}$contents of leaf occurred between different water table levels (Table 1). The average $\mathrm{Cl}^{-}$allocation in the leaf was about $40 \%$, and on average less than $40 \%$ of $\mathrm{Cl}^{-}$accumulated in root (taproot and fibrous root), which was different from $\mathrm{Na}^{+}$allocation (Fig. 3).

Effect of salt and water table on osmotic parameters

Proline is a typical organic osmolyte closely related to osmotic stress intensity. When there was no salt stress, proline concentrations increased significantly with increasing water table (Fig. 4). At the same water table level, proline concentrations increased dramatically with the increasing of salt stress. However, no significant differences were observed at the $30 \mathrm{~cm}$ water table treatment among different salt stresses.

The response of soluble sugar concentrations to salt stress was observed differently compared to the responses of proline concentrations. With the increase in salt stress, the soluble sugar concentrations decreased significantly at all levels of water table (Fig. 4). No obvious trends were observed between different water tables.

The protein content was the lowest in the interaction of control water treatment and $0 \%$ salt treatment. With the increasing of salt stress and water table level, the protein content increased dramatically (Fig. 4).

\section{Discussion}

As one of the important, widespread and constructive wetland plant species over the YRD, $P$. australis is often the first choice for wetland restoration. So it is essential to understand the ecological responses of $P$. australis to the interactive effects of water table level and salt stress. The present study showed that $0 \mathrm{~cm}$ water table is the most suitable level for the growth of $P$. australis, with plant height, shoot diameter, tiller number, and leaf area all showing better performance 

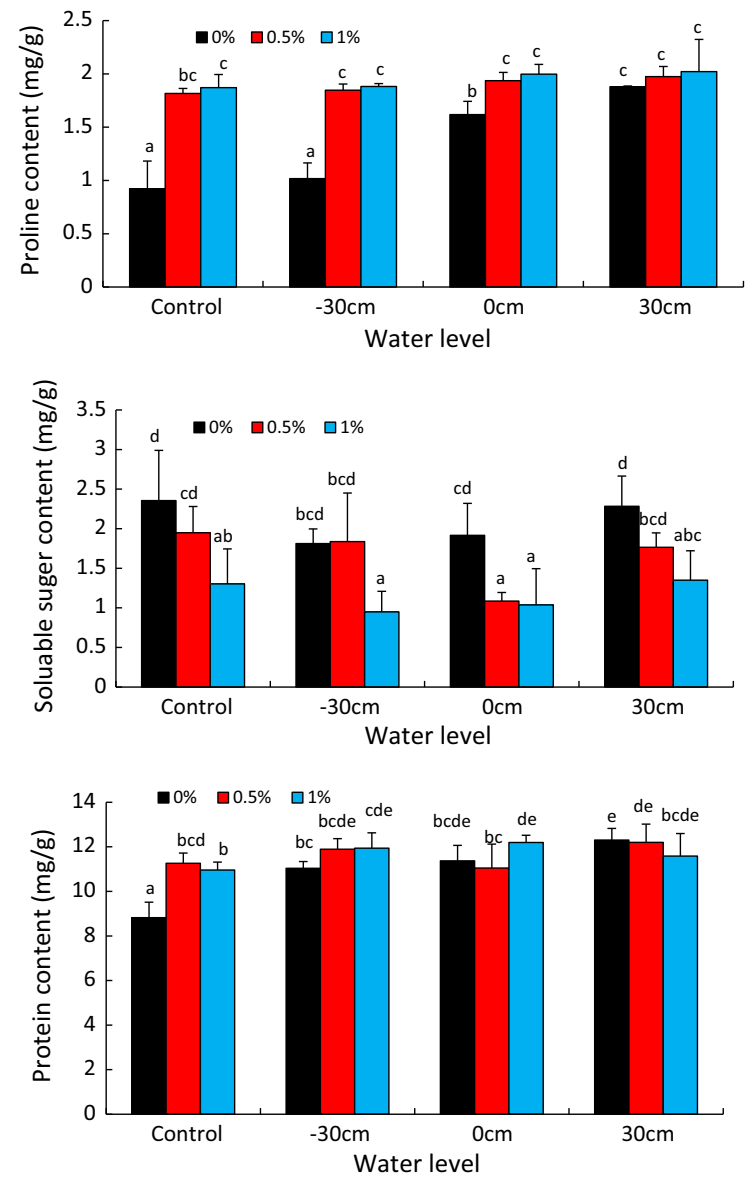

Fig. 4 Effect of salt stress and water level on proline contents, soluble sugar content and protein contents in leaves of $P$. australis. In each column, the data markers identified with the same letters are not significantly different $(p<0.05)$ according to a least significant difference test

compared to other water tables. Similar relationships were also reported by previous studies. Suaeda salsa, which is the main pioneer plant species in the YRD, showed significant increases in both plant height and branch number with decreasing water table depth (Guan et al. 2011). Similarly, the shoot biomass response of Asteriscus maritimus (L.) Less (= Pallenis maritima (L.) Greuter), which is often planted in saline agricultural land, is severely affected by a combination of salt and waterlogging treatments (Rodríguez et al. 2005), which confirmed that, in general, the first symptoms of environmental stress in plants are the restriction of plant shoot growth and leaf expansion (Sánchez-Blanco et al. 1998; Rodríguez et al. 2005). Based on our results, we can speculate that a moderate growth strategy, such as a slowing down of growth rate and consistent tiller number under saline conditions (as occurs at $1 \%$ salt solutions), strongly determines higher tolerance to a saline waterlogging environment, such as the intersection of Yellow River freshwater and Bohai seawater in the YRD.

Interestingly, the $0.5 \% \mathrm{NaCl}$ treatment increased the aboveground biomass (both shoot and leaf) of $P$. australis, with the exception of shoot biomass in control water treatment. This indicated a positive response from $P$. australis growth to mild salt stress when compared to no salt and high levels of salt stress, especially within a suitable water table conditions. The biomass accumulation results confirmed our first and second hypothesis, which predicted that in higher saline condition, an appropriate water table level could increase plant biomass when compared with control or higher water table treatment. One primary reason could be the low oxygen status under higher water table levels and concomitant energy shortage (Mommer et al. 2006; Rodríguez et al. 2005). When a seedling is exposed to a high water table, anaerobic respiration and reserved carbohydrates will be used to tolerate long-term anoxic conditions (Gibbs and Greenway 2003). Voesenek reported that plants can elongate the shoot organs out of water to restore contact with the atmosphere (Voesenek et al. 2003). Similar results were observed in this study, showing the shoot biomass allocation increased at the high water table level compared to lower water table treatments. Moreover, we also found that the fibrous root biomass allocation increased in higher water table treatments $(0$ and $30 \mathrm{~cm})$, whereas leaf biomass largely decreased. One point of view believes that the developed fibrous root system in flooding is not the most crucial requirement for survival, and furthermore, these roots need a continuous oxygen supply (Vartapetian and Jackson 1997). However, results similar to this study were obtained elsewhere (Banach et al. 2009). It is generally believed that more tolerant species can photosynthesize under water and also possess an efficient within-plant system of gas transport (Blom et al. 1994; Banach et al. 2009).

Previous studies have shown that as a salt tolerant plant, when $P$. australis is exposed to saline conditions, ion exclusion from plant tissues is the first attempt to protect the plant against salt stress, and the ion uptake is most likely isolated in the vacuoles (Achenbach et al. 2013; Achenbach and Brix 2014). 
After 6 months of exposure to saline conditions in this study, the $\mathrm{Na}^{+}$and $\mathrm{Cl}^{-}$contents of $P$. australis increased substantially, and water table treatments had no significant effects on ion contents. The allocation of $\mathrm{Na}^{+}$and $\mathrm{Cl}^{-}$in different organs showed different trends, with $53.9 \%$ of $\mathrm{Na}^{+}$being accumulated in belowground organs, while about $64.9 \%$ of $\mathrm{Cl}^{-}$ accumulated in aboveground organs. Similar results were also found by a previous study (Achenbach and Brix 2014). This could be attributed to a decrease in the $\mathrm{Na}^{+}$release rate from xylem parenchyma cells to xylem, and/or an occurrence of $\mathrm{Na}^{+}$retranslocation from shoot to root (Matsushita and Matoh 1991).

Organic solutes, such as proline, may accumulate in the cytoplasm and organelles to balance the low osmotic potential in the vacuole when in stress environments such as salt or flooding (Hasegawa et al. 2000). This is consistent with the results obtained in this study, in which the accumulation of proline was clearly a response to osmotic stress to salt and the combination of salt and water table. Previous studies have demonstrated that proline could preserve protein structure and activity and reduce enzyme denaturation by inactivating hydroxyl radicals and other reactive chemical species (Saradhi et al. 1995; Yang et al. 2007). This finding was verified by our experimental results. The protein content of leaves in different treatments showed similar trends with proline content (Fig. 4). Soluble sugar is another important organic osmotic compound, which can contribute to up to $50 \%$ of the total osmotic potential in some glycophytes subject to salt stress (Ashraf and Harris 2004; Cram 1976). However, salinity may increase soluble sugar in some plant species (De Lacerda et al. 2003) or decrease it in others (Agastian et al. 2000). The soluble sugar in the leaves of this study showed a significant decrease with increasing salt stress. No significant effects were observed in water table treatments or from the combination of salt stress and water table levels.

\section{Conclusions}

In summary, understanding the mechanism of the typical dominant plants in resisting different saline and water table stresses is important for the ecological recovery and exploitation of the newly accreted coastal wetland soil in regions of active biogeochemical interactions between land and ocean waters. $P$. australis plant could adapt to the different saline and water table depth environments in the YRD through the slowing down of growth rate, keeping a consistent tiller number and adjusting the biomass allocation of different organs. The plant traits of osmoregulation are another important survival mechanism in saline wetlands, which include the exclusion of inorganic ions dominated by $\mathrm{Na}^{+}$and $\mathrm{Cl}^{-}$, and the accumulation of organic solutes dominated by proline. The results elucidated the adaptive mechanism of the typical $P$. australis clone plant in response to saline and water table stress from ecophysiological aspects. The study could provide fundamental guidance for wetland restoration projects and wetland sustainable use in coastal zones such as the YRD.

Acknowledgments We thank the Editor and two anonymous reviewers of this paper for their critical and helpful comments on an earlier version of the manuscript. We are grateful for support from the Project of the Cultivation Plan of Superior Discipline Talent Teams of Universities in Shandong Province: "the Coastal Resources and Environment team for Blue-Yellow Area," the National Natural Science Foundation of China (31300325 and 41301052), the Program of Science and Technology Service Network Initiative, Chinese Academy of Sciences (No. KFJ-EW-STS-127). We extend our thanks to Dr. Jingtao Liu, Dr. Wenjun Xie, Dr. Jingkuan Sun and Dr. Ximei Zhao for their helpful work during this study.

\section{References}

Achenbach L, Brix H (2014) Can differences in salinity tolerance explain the distribution of four genetically distinct lineages of Phragmites australis in the Mississippi River Delta? Hydrobiologia 737:5-23

Achenbach L, Eller F, Nguyen LX, Brix H (2013) Differences in salinity tolerance of genetically distinct Phragmites australis clones. AoB Plants 5:plt019. doi:10.1093/aobpla/ plt019

Agastian P, Kingsley S, Vivekanandan M (2000) Effect of salinity on photosynthesis and biochemical characteristics in mulberry genotypes. Photosynthetica 38:287-290

Ashraf M, Harris P (2004) Potential biochemical indicators of salinity tolerance in plants. Plant Sci 166:3-16

Banach K, Banach AM, Lamers LP, De Kroon H, Bennicelli RP, Smits AJ, Visser EJ (2009) Differences in flooding tolerance between species from two wetland habitats with contrasting hydrology: implications for vegetation development in future floodwater retention areas. Ann Bot 103:341-351

Barbier EB, Hacker SD, Kennedy C, Koch EW, Stier AC, Silliman BR (2011) The value of estuarine and coastal ecosystem services. Ecol Monogr 81:169-193 
Blom C, Voesenek L, Banga M, Engelaar W, Rijnders J, Van de Steeg H, Visser E (1994) Physiological ecology of riverside species: adaptive responses of plants to submergence. Ann Bot 74:253-263

Bradford MM (1976) A rapid and sensitive method for the quantitation of microgram quantities of protein utilizing the principle of protein-dye binding. Anal Biochem 72:248-254

Brix H (1999) Genetic diversity, ecophysiology and growth dynamics of reed (Phragmites australis). Aquat Bot 64:179-184

Burdick DM, Buchsbaum R, Holt E (2001) Variation in soil salinity associated with expansion of Phragmites australis in salt marshes. Environ Exp Bot 46(3):247-261

Cram WJ (1976) Negative feedback regulation of transport in cells. The maintenance of turgor, volume and nutrient supply. In: Lüttge U, Pitman MG (eds) Transport in plant II: part A cells. Springer, Berlin, pp 284-316

Cui B, Qiang H, Zhao X (2008) Ecological thresholds of Suaeda salsa to the environmental gradients of water table depth and soil salinity. Acta Ecol Sin 28:1408-1418

De Lacerda CF, Cambraia J, Oliva MA, Ruiz HA, Prisco JT (2003) Solute accumulation and distribution during shoot and leaf development in two sorghum genotypes under salt stress. Environ Exp Bot 49:107-120

Deng Z, An S, Zhao C, Chen L, Zhou C, Zhi Y, Li H (2008) Sediment burial stimulates the growth and propagule production of Spartina alterniflora Loisel. Estuar Coast Shelf Sci 76:818-826

Di Bella CE, Striker GG, Escaray FJ, Lattanzi FA, Rodríguez AM, Grimoldi AA (2014) Saline tidal flooding effects on Spartina densiflora plants from different positions of the salt marsh. Diversities and similarities on growth, anatomical and physiological responses. Environ Exp Bot 102:27-36

Gibbs J, Greenway H (2003) Mechanisms of anoxia tolerance in plants. I. Growth, survival and anaerobic catabolism. Funct Plant Biol 30:353

Guan B, Yu J, Wang X, Fu Y, Kan X, Lin Q, Han G, Lu Z (2011) Physiological responses of halophyte Suaeda salsa to water table and salt stresses in coastal wetland of Yellow River Delta. Clean Soil Air Water 39:1029-1035

Guo WY, Lambertini C, Li XZ, Meyerson LA, Brix H (2013) Invasion of Old World Phragmites australis in the New World: precipitation and temperature patterns combined with human influences redesign the invasive niche. Global Change Biol 19(11):3406-3422

Hasegawa PM, Bressan RA, Zhu JK, Bohnert HJ (2000) Plant cellular and molecular responses to high salinity. Annu Rev Plant Biol 51:463-499

He Q, Cui B, Zhao X, Fu H, Xiong X, Feng G (2007) Vegetation distribution patterns to the gradients of water depth and soil salinity in wetlands of Yellow River Delta, China. Wetland Sci 5:208-214

He Q, Cui B, Zhao X, Fu H (2008) Niches of plant species in wetlands of the Yellow River Delta under gradients of water table depth and soil salinity. J Appl Ecol 19:969-975

Lucas KL, Carter GA (2013) Change in distribution and composition of vegetated habitats on Horn Island, Mississippi, northern Gulf of Mexico, in the initial five years following Hurricane Katrina. Geomorphology 199:129-137
Matsushita N, Matoh T (1991) Characterization of $\mathrm{Na}^{ \pm}$exclusion mechanisms of salt-tolerant reed plants in comparison with salt-sensitive rice plants. Physiol Plantarum 83:170-176

Mauchamp A, Mésleard F (2001) Salt tolerance in Phragmites australis populations from coastal Mediterranean marshes. Aquat Bot 70(1):39-52

Mommer L, Lenssen JPM, Huber H, Visser EJW, Kroon HD (2006) Ecophysiological determinants of plant performance under flooding: a comparative study of seven plant families. J Ecol 94(6):1117-1129

Ren M, Walker JH (1998) Environmental consequences of human activity on the Yellow River and its Delta China. Phys Geogr 19:421-432

Rodríguez P, Torrecillas A, Morales MA, Ortuño MF, SánchezBlanco MJ (2005) Effects of $\mathrm{NaCl}$ salinity and water stress on growth and leaf water relations of Asteriscus maritimus plants. Environ Exp Bot 53:113-123

Sánchez-Blanco MJ, Morales MA, Torrecillas A, Alarcón JJ (1998) Diurnal and seasonal osmotic potential changes in Lotus creticus creticus plants grown under saline stress. Plant Sci 136:1-10

Saradhi PP, AliaArora S, Prasad K (1995) Proline accumulates in plants exposed to UV radiation and protects them against UV-induced peroxidation. Biochem Biophys Res Commun 209:1-5

Shan K (2007) Theory, methodology and practices of wetland ecological restoration in Yellow River Delta Nature Reserve. Wetl Sci Manag 3:16-20

Vartapetian BB, Jackson MB (1997) Plant adaptations to anaerobic stress. Ann Bot 79:3-20

Voesenek LA, Benschop JJ, Bou J, Cox MC, Groeneveld HW, Millenaar FF, Vreeburg RA, Peeters AJ (2003) Interactions between plant hormones regulate submergence-induced shoot elongation in the flooding-tolerant dicot Rumex palustris. Ann Bot 91:205-211

Wang ZY, Liang ZY (2000) Dynamic characteristics of the Yellow River mouth. Earth Surf Proc Land 25:765-782

Wang H, Yang Z, Saito Y, Liu JP, Sun X (2006) Interannual and seasonal variation of the Huanghe (Yellow River) water discharge over the past 50 years: connections to impacts from ENSO events and dams. Global Planet Change 50:212-225

Wang X, Yu J, Zhou D, Dong H, Li Y, Lin Q, Guan B, Wang Y (2012) Vegetative ecological characteristics of restored reed (Phragmites australis) wetlands in the Yellow River Delta, China. Environ Manag 49:325-333

Wu D, Liu J, Wang W, Ding W, Wang R (2009) Multiscale analysis of vegetation index and topographic variables in the Yellow River Delta of China. Chin J Plant Ecol 33(02):237-245

Xia J, Zhang S, Guo J, Rong Q, Zhang G (2015) Critical effects of gas exchange parameters in Tamarix chinensis Lour on soil water and its relevant environmental factors on a shell ridge island in China's Yellow River Delta. Ecol Eng 76:36-46

Yang C, Chong J, Li C, Kim C, Shi D, Wang D (2007) Osmotic adjustment and ion balance traits of an alkali resistant halophyte Kochia sieversiana during adaptation to salt and alkali conditions. Plant Soil 294:263-276 
Yu J, Li Y, Han G, Zhou D, Fu Y, Guan B, Wang G, Ning K, Wu $\mathrm{H}$, Wang J (2013) The spatial distribution characteristics of soil salinity in coastal zone of the Yellow River Delta. Environ Earth Sci 72:589-599
Zhu G, Deng X, Zuo W (1983) Determination of free proline in plants. Plant Physiol Commun 1:35-37 